\title{
Existence of homologous sequences corresponding to cDNA of the ver gene in diverse higher plant species
}

\author{
JIA Shi Qian ${ }^{1}$, Wei Dong YONG ${ }^{1}$, Wen Zhong XU ${ }^{1}$, Yun Yuan XU ${ }^{1}$, Jin Song WU ${ }^{1}, \mathrm{Kang}_{\text {CHONG }}$, \\ *, Ke Hui TAN ${ }^{1}$, Zhi Hong XU ${ }^{1,2}$ \\ ${ }^{1}$ Research Center for Molecular and Developmental Biology, Institute of Botany, Chinese Academy of Sciences, \\ Beijing 100093, China \\ ${ }^{2}$ Chinese Academy of Sciences, Beijing 100864, China
}

\begin{abstract}
The presence of DNA homologues corresponding to verc203 (vernalization-related cDNA clone) was investigated by molecular hybridization techniques. The genes were detected in 16 plant species that cover 12 subclasses of the Takhtajan system of angiosperms classification including diverse model species. The results of Southern blot analysis showed a low copy number of this gene existed in rice, wheat, barley and Arabidopsis. The hybridization result of PCR products demonstrated the conservation of the gene corresponding to ver203 in diverse plants. The phylogenetic tree of the ver203 gene in tested plants was supported by evolution relationship of species. The ver203 gene expressed in a vernalized plumule winter wheat, instead of the root. And the endosperm before the treatment was essential for the ver203 expression during vernalization in wheat. In Arabidopsis thaliana, the pattern of expression showed that the gene corresponding to ver203 was expressed at low temperature for 14 days. Gibberellin $\left(\mathrm{GA}_{3}\right)$ may accelerate the expression of ver203 gene in Arabidopsis exposed to low temperature. However, it could not replace vernalization treatment to initiate the gene expression.
\end{abstract}

Key words: Ver203 gene, vernalization-related gene, flower initiation, homologous DNA, Takhtajan system.

\section{INTRODUCTION}

In the vast majority of higher plants, a transition from vegetative growth to reproductive development is strongly influenced by a set of environmental factors, such as photoperiod, temperature etc. Both winter trait and biennial plants require a period of low temperature for switching from vegetative to reproductive growth, and this process is known as vernalization. Several physiological and genetic investigations showed that the vrn-genes control the vernalization traits of higher plants. Although the vrn genes have not been cloned yet, they were

* Corresponding author: Dr. Kang CHONG, Research Center for Molecularand Developmental

Biology Institute of Botany, Chinese Academy of Sciences, Beijing 100093, China

Tel/Fax: 86-10-82594821, Email: chongk@public.east.net.cn or chongk@ns.ibcas.ac.cn mapped on chromosome in wheat, such as, VRN1, VRN4, VRN3 and VRN5 at chromosome 5A, 5B, 5D and 7D, respectively[1]. VRN1 and VRN2 were located at chromosome III and IV, respectively in Arabidopsis[2]. Moreover a series of vernalization related genes were separated by approaches of the differential screening and mRNA differential display. The cDNAs of ver203, ver17 and vrc79 gene have been reported in succession in wheat since 1994[3-5]. In recent years, map-based cloning strategy has been used to clone vernalization related genes, such as CO (CONSTENTS)[6], FCA [7], FLC (FLOWERING LOCUS C)[18], FLF (FLOWERING LOCUS F)[9], and FRI (FRIGIDA)[10], in Arabidopsis. In addition, FKF1 (FLAVINBINDING, KELCH REPEAT, F BOX) was identified to be a clock-controlled gene that regulates the 
Existence of the ver homologous gene in diverse higher plant species

transition to flowering. Deletion of FKF1 causes late flowering response to vernalization and GA (gibberellin)[11]. Based on studies of GAs on physiological function and mutants, it was known that GA metabolism affected vernalization in higher plants.

The ver203, a novel vernalization-related gene, was identified to possess an important function in initiating flowering in wheat by antisense RNA strategy[4], [12]. Sequence analysis of homologue search in the nucleotide sequence database of GenBank, EMBL and DDBJ, showed that the ver203 F, one of ver 203 family members, shared a homological sequence with a gene of protein induced by jasmonate in Hordeum Vulgare. This suggested that the gene might be involved in the flowering induced by vernalization process through a signal transduction mediated by jasmonate[13]. The gene's physiological characteristics, such as, its conservation in other species, expression specificity and the relationship between ver203 and GA, should be addressed. In this paper, the conservation of wheat ver203 gene in diverse plant species and its expression patterns in wheat and Arabidopsis were investigated to illustrate its function in plant development.

\section{MATERIALS AND METHODS}

\section{Plant materials}

Seeds of Oryza sativa L., Nicotiana tabacum L., Brassica chinensis L., Hordeum vulgare Linn., Brassica oleracea L., and Raphanus sativus L. were germinated and then grown in soil under appropriate conditions. The leaves were collected from the 15-20 days' old plants of the respective genera under investigation for the genomic DNA extraction[14]. Representative samples of diverse plant species that cover every subclass of the Takhtajan classification system of higher plants (i.e., Crataegys pinnatifida, Eupatorium lindleyanum, Thalictrum sp., Polygonum cuspidatum, Macrocarpium officinalis, Actinidia chinensis, Hosta plantaginea, Polygonatum macropodium, Pinellia pedatisecta, Magnolia denudata, Chamaedorea elegans, Sagittaria trifolia, Nymphaea sp,. Cercidiphyllum japonicum, Tradescantia reflexa, and Nelumbo nucifera) were collected from the Beijing Botanical Garden of the Institute of Botany, Chinese Academy of Sciences, and the DNA was extracted from these leaves.

Seeds of Arabidopsis thaliana (Columbia ecotype) were germinated on MS (Murashige and Skoog, 1962) medium at room temperature $\left(25^{\circ} \mathrm{C}\right)$ with $10 \mathrm{~h}$ photoperiod $(10 / 14 \mathrm{~h}$ light dark cycle). After $2 \mathrm{w}$ of germination and growth, the plants were used for treatment experiments. Some of the seedlings were exposed to 4$8{ }^{\circ} \mathrm{C}$ for 1 and $2 \mathrm{w}$ for vernalization (low temperature) treatment, and the rest were kept at room temperature as control. Seedlings germinated in the MS medium in the presence of $\mathrm{GA}_{3}$ up to $10 \mathrm{mM}$ are defined as the GA treatment. Only the shoot portion was used to extract DNA and RNA of these samples in this investigation.

Winter wheat (Triticum aestivum L.cv Jingdong No.1) seeds were surface-sterilized in $2 \%$ aqueous $\mathrm{NaOCl}$ solution for $20 \mathrm{~min}$. After washed in autoclaved water overnight, seeds were germinated on moist filter paper at $4-8 \mathrm{oC}$ for $28 \mathrm{~d}$ as the vernalization treatment and some seeds were germinated at $25 \mathrm{oC}$ for $5 \mathrm{~d}$ as control. The plumules were used to extract both DNA and RNA.

\section{Extraction of DNA and RNA}

Total genomic DNA was isolated from leaves of plant by using a method described by Dellaporta, et al. (1983)[14]. The extraction buffer contains $200 \mathrm{mM}$ Tris-HCl pH7.5, $250 \mathrm{mM} \mathrm{NaCl}, 25$ $\mathrm{mM}$ EDTA, 0.5\% SDS and 1\% 2-Mercaptoethanol. Total RNA was extracted with a Trizol reagent (Gibco. BRL USA) according to the protocol provided by the manufacturer.

\section{DNA gel blot and dot blot analysis}

DNA was digested with appropriate restriction enzymes and fractionated on a 1.0\% agarose gel. After the DNA was blotted onto a nylon membrane (positively charged, Boehringer Mannheim, Germany), the filters were probed with the ${ }^{32} \mathrm{P}$-labelled verc203 fragment in a hybridization solution containing $7 \%$ SDS, $50 \%$ Formamide, $20 \mathrm{mM}$ EDTA, $10 \mathrm{mM} \mathrm{Na} \mathrm{HPO}_{2} \mathrm{pH}$ 7.0, $1 \%$ blocking reagents (Boehringer Mannheim, Germany), 15\% PEG6000 and $5 \times$ SSC. Membranes were washed at $60^{\circ} \mathrm{C}$ in a washing solution containing $0.5 \times \mathrm{SSC}$ and $0.5 \% \mathrm{SDS}$. And the filter was exposed to Kodak X-Omat films[15].

The DNA dot blot analysis was performed as described above except that DNA was blotted onto the membrane directly.

\section{RNA gel blot analysis}

Total RNA was separated on a 1.0\% agarose gel denatured with formaldehyde (Sambrook et al, 1989) and hybridized with radiolabeled verc203 probe. Hybridization was carried out in a solution containing $5 \times$ Denhart' s reagent, $6 \times \mathrm{SSC}, 10 \mathrm{mM}$ EDTA, $0.5 \%$ SDS and $100 \mathrm{mg} / \mathrm{ml}$ salmon sperm DNA at $68 \mathrm{oC}$. Blots were washed at the same temperature in a washing solution containing $0.5 \% \mathrm{SDS}$ and $0.1 \times \mathrm{SSC}$. The probed filters were exposed to phosphate screener (Phosphor Imager 445, USA).

\section{PCR Amplification and blot analysis}

PCR amplification was performed as the following: denaturing for $45 \mathrm{sec}$ at $95^{\circ} \mathrm{C}$, annealing for $50 \mathrm{sec}$ at $62^{\circ} \mathrm{C}$ and extending for $1 \mathrm{~min}$ at $72^{\circ} \mathrm{C}$ for 35 cycles. The $50 \mu \mathrm{L}$ reaction volume consisted of $25 \mathrm{ng}$ of genomic template DNA, $50 \mathrm{pmol}$ of each primer, $2 \mu \mathrm{M}$ $\mathrm{MgCl}_{2}, 1 \times \mathrm{PCR}$ reaction buffer and 5 units of Taq DNA polymerase. The primer sequences were 5 ' -TCCACACCCAGCCACTCACCC3' (forward) and 5' - GGGGCGCGATTGCATGCGCGG-3' (reverse) from verc 203 sequence. PCR products were electrophoresed on a $1.2 \%$ agarose gel and blotted. Hybridization was done with the same method as Southern blot described above.

\section{RESULTS AND DISCUSSION}


DNA homologues of genes corresponding to ver203

Among the systematic classification of Angiosperms, Takhtajan classification is one of the most acceptable systems at present (1987). Takhtajan revised and replenished Bessey' s evolution tendency of angiosperms and published his own system based on several decades' study on morphology and anatomy of higher plants[16]. The system consists of 12 subclasses, 53 superorders and 166 orders based on the opinion that Magnoliidae is the primitive type of angiosperms[16]. Sixteen species used in the experiment (Crataegys pinnatifida, Eupatorium lindleyanum, Thalictrum sp., Polygonum cuspidatum, Macrocarpium officinalis, Actinidia chinensis, Hosta plantaginea, Polygonatum macropodium, Pinellia pedatisecta, Magnolia denudata, Chamaedorea elegans, Sagittaria trifolia, Nymphaea sp., Cercidiphyllum japonicum, Tradescantia reflexa, and Nelumbo nucifera) were representatives for each subclass of the Takhtajan system, respectively. Genomic DNA isolated from the 16 species were blotted on a nylon membrane and hybridized with the verc203 probes radioactive labeled. All of the 16 tested species from 12 subclasses of the Takhtajan system showed positive signals to the verc203 probe although the strength of hybridization signals was much different from one another (Fig 1). The strongest signal appeared from Hosta plantaginea, and the weakest from Polygonum cuspidatum.

The DNA dot blot analysis with a probe of verc203 showed clear hybridization signals in the diverse plant species (Fig 1). The blot analysis of PCR product provided another positive evidence that the genes corresponding to ver203 were involved in genome of the diverse model species tested (Fig 2).

Several homologues fragments were cloned by using approach of PCR from the representative species in evolution, such as, magnolia, rice, wheat, orchid, Arabidopsis and Hoata plantaginea. The evolutionary relationship between ver203 of wheat and homologues of the other species were analyzed using the Pileup program of GCG software package (Fig 3). It was found that available homologues of different plant origins were classed into three groups. Homologues sequence from Arabidopsis, orchid and the rest species of the experiment were unattached

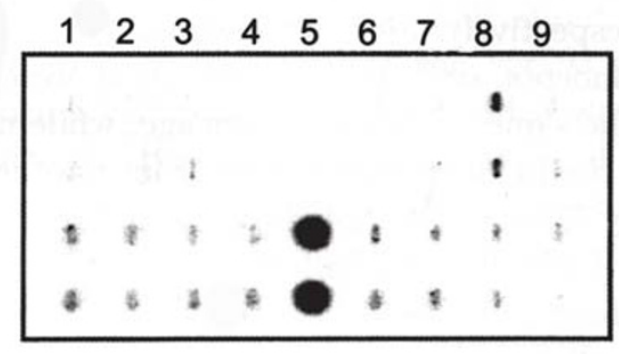

Fig 1. DNA dot blot analysis of plant species that cover 12 subclasses of the Takhtajan system of classification of angiosperms (1987)

Row 5 in the Line $1 \& 2$ and the line $3 \& 4$ was negtive and positive control, respectively. Line1 and 2: row1, 2, 3, 4, 6, 7, 8 and 9 were Crataegys pinnatifida, Eupatorium lindleyanum, Thalictrum sp., Polygonum cuspidatum, Macrocarpium officinalis, Actinidia chinensis, Hosta plantaginea and Polygonatum macropodium, respectively. Line 3 and 4: row 1, 2, 3, 4, 6, 7, 8 and 9 were Pinellia pedatisecta, Magnolia denudata, Chamaedorea elegans, Sagittaria trifolia, Nymphaea sp., Cercidiphyllum japonicum and Tradescantia reflexa and Nelumbo nucifera, respectively.

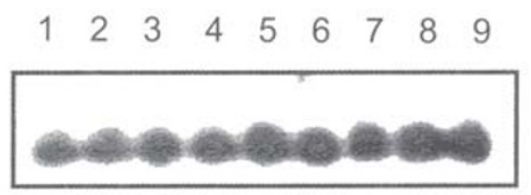

Fig 2. Blot analysis of PCR product in the diverse model plants

Lane 1, Oryza sativa L. cv. Zhongzuo No. 93; Lane 2, Raphanus sativus L. cv. Mikefeng5cun; Lane 3, Hordeum vulgare Linn. cv. Goft; Lane 4, Brassica Oleracea L. cv. Zaofeng No.1; Lane 5, Brassica chinensis L. cv. Xinwuyueman; Lane 6, Nicotiana tabacum L. cv. W38; Lane 7, Triticum aestivum L. cv. Jing771 (Spring wheat); Lane 8, Triticum aestivum L. cv. Jingdong No.1 (Winter wheat); Lane 9, Arabidopsis thaliana

\section{Phylogenetic Tree}

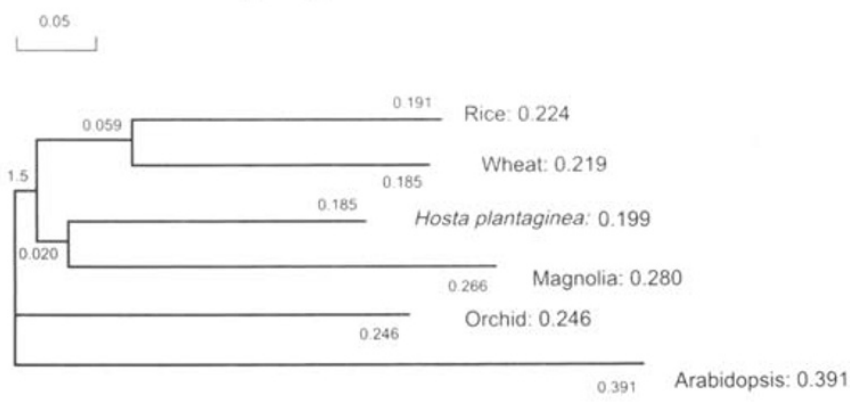

Fig 3. Phylogenetic relationship of ver203 gene 
group, respectively. More interestingly, that isolated from monocots, such as, rice and wheat were found within the same evolutionary lineage, while magnolia and Hoata plantaginea were from another evolutionary lineage. The phylogenetic relationship of ver203 gene in diverse plant species corroborated the evolutionary relationship of species[16]. The results of the earlier study showed that the ver203 plays a role in the initiation of flowering and floral development[12]. The homologue sequence corresponding to ver203 is widely distributed in diverse higher plants which indicates that these plants may share some similar common pathways of gene control to initiate flowering. There is another possibility that the genes not only response to vernilization for flowering but also have other functions in the rest plants which do not have the requirement of vernalization. The gene functions in plants of both winter and nonwinter traits remain to be investigated.

Southern blot analysis of DNA from wheat, rice, Arabidopsis and barley

Southern blot analysis of some model plants was done to investigate the copy number of homologous genes corresponding to ver203. Genomic DNAs from Arobidopsis, rice, barley and wheat were cleaved by different restriction enzymes, such as, EcoRI, BamHI and HindIII. The results showed that the DNA homologues corresponding to verc203 were a single band in Arabidopsis, wheat and rice (Fig 4). Unlike these plants, barley showed up to three bands
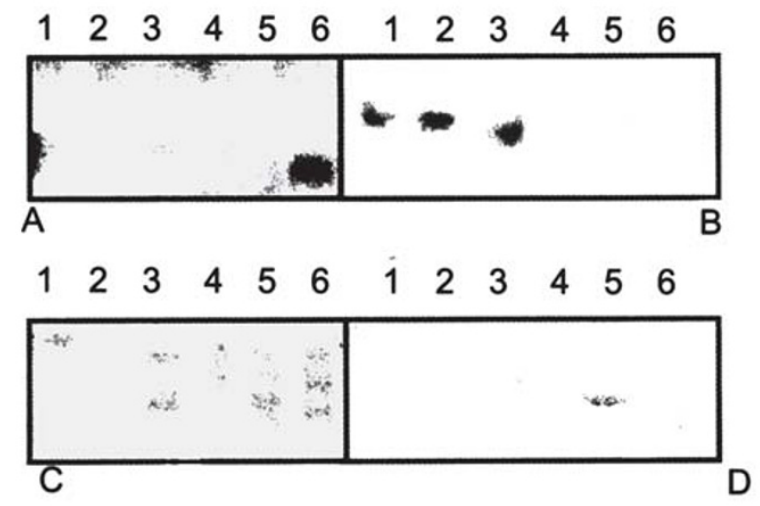

Fig 4. Southern blot analysis of DNA from Arabidopsis, wheat, barley and rice

A, B, C, and D was the Southern blot of Arabidopsis, rice, barley and wheat, respectively. DNA was cleaved using EcoRI(L 1), BamHI(L 2), HindIII(L 3), EcoRI + BamHI(L 4), BamHI + HindIII(L 5), EcoRI + HindIII (L 6). in the Southern blot. The copy number of gene corresponding to ver203 showed the diversity between barely and other tested plants. Bioinformatic analysis of BLASTN search in Arabidopsis genome sequence showed verc203 shared $95 \%$ sequence in a short region of unknown functional hypothetical protein gene (At1g22000). It may suggest that the homology at DNA level might be relatively low.

Gene expression of verc203 homologue in wheat and Arabidopsis

The expression pattern of verc203 homologous gene showed aspecificity for vernalization treatment in winter wheat (Triticum aestivum L. cv) Jingdong No.1). It expressed under the condition of $4 \mathrm{oC}$ for $28 \mathrm{~d}$ (vernalized) in the winter wheat. It, however, did not express under non-vernalization even vernalization for less than $28 \mathrm{~d}$ or devernalization conditions[4]. That means the gene is different from general stress response gene since general stress genes have a quick response to the stress conditions [18]. Dot blot analysis showed that the gene expressed only in a vernalized plumule rather than a root in wheat (Fig 5). That means the specificity of expression patterns displayed not only in the temporality of development but also in the spatiality of tissues, which was also confirmed by results of hybridization in situ. And when a plant was treated by jasmonate, its family member, ver $203 \mathrm{~F}$ had the same patterns as that by vernalization[19].

As early as in 1944, it was suggested that an active sugar metabolism is necessary for vernalization process for flowering[18]. A seedling from in vitro embryo could not response to vernalization. And sugar did reverse that to the normal response to vernalization[18]. Our data provided a novel molecular evidence for that. Hybridization result of RNA from the vernalized seedling from seeds with endosperm showed clear bands with positive signals under low

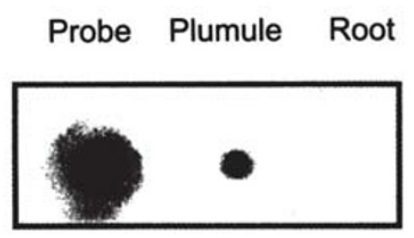

Fig 5. Expression pattern of the ver203 gene in different tissues in wheat 
stringency hybridization conditions. On the contrary, the main band disappeared on the lane of the RNA from vernalized seedlings from seeds which endosperm was removed before germination and treatment of vernalization at the same hybridization conditions (Fig 6). The results suggested that gene expression of the ver203 depended on endosperm in wheat during vernalization. One more band appeared on lanes of the vernalized seedlings under low stringency hybridization conditions. The reason might be considered as transcriptive intermediate forms or preforms such as pre-mRNA[20],[21]. Further investigation is needed.

Arabidopsis is the most useful model in plant molecular genetics. And it requres vernalization for flowering as known. Therefore, the expression pattern of the homologue gene of ver203 in Arabidopsis thaliana is an interesting way to understand the gene function.

It was known that GA metabolism, affected vernalization in higher plants. And it could completely or partially replace vernalization treatment for flow-

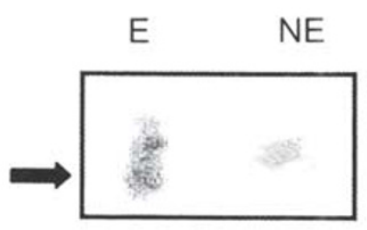

Fig 6. Effect of endosperm on expression of the ver203 gene $\mathrm{E}$ : vernalized seedlings from seeds with endosperm; NE, ones from seeds whose endosperm was removed before germination and treatment of vernalization.

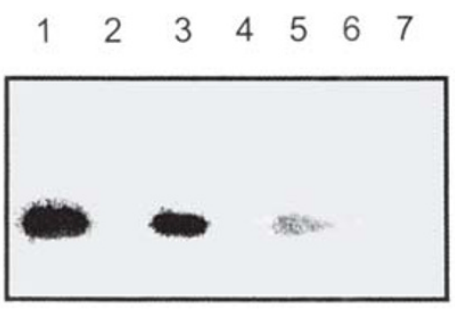

Fig 7. Expression pattern of the DNA homologous corresponding to ver203 in Arabidopsis thaliana

Lane 1, positive control (winter wheat at $4^{\circ} \mathrm{C}$ for $28 \mathrm{~d}$ ); Lane 2 , the negative control (unvernalized winter wheat), Lane 3 , Arabidopsis thaliana grew in MS media involving $10 \mu \mathrm{M}$ GA3 at $4{ }^{\circ} \mathrm{C}$ for $14 \mathrm{~d}$; Lane 4 , Arabidopsis thaliana grew in MS media involving $10 \mu \mathrm{M}$ GA3 at $4^{\circ} \mathrm{C}$ for $7 \mathrm{~d}$; Lane 5; Arabidopsis thaliana at $4^{\circ} \mathrm{C}$ for $14 \mathrm{~d}$; Lane 6 , Arabidopsis thaliana at $4^{\circ} \mathrm{C}$ for $7 \mathrm{~d}$; Lane 7 , Arabidopsis thaliana at $22^{\circ} \mathrm{C}$ for $7 \mathrm{~d}$. ering in some species[22]. To understand the relationship between function of the ver203 gene and GA during vernalization, Arabidopdsis was used to analysize the gene expression patterns. The result of Fig 7 showed that the ver203 expression patterns in Arabidopsis were similar to those in wheat during vernalization. A band appeared on the lane of plant vernalized for $14 \mathrm{~d}$ in Arabidopsis although it was weaker. No any hybridization signals, however, appeared on both the control and the material vernalized for $7 \mathrm{~d}$. In our GA-experimental system of Arabidopsis, a stronger signal band appeared on the lane of GA3 treatment during vernalization. On the contrary, no band was seen on the lane of treatment of GA alone. Those data showed that GA3 did accelerate but not replace vernalization to induce the ver203 gene expression for flowering (Fig 7). The outcome of GA treatment was similar to that of vernalization in many species. Results above supported a hypothesis that the pathways of vernalization and GA to control flowering are independent to each other[2],[17]. Vernalization is controlled by methylation of the key genes in metabolism pathway of GA[23]. Our data of ver203 expression pattern suggested a model of gene control for flowering as Fig 8 showed. GA and vernalization are two pathways in controlling the initiation of flowering in spite of the fact that the synthesis of GA is stronger at low temperature. The ver203 is one of the most important genes in the vernalization pathway. There may be some partial overlaps between the two pathways. The gene may also be a downstream member to

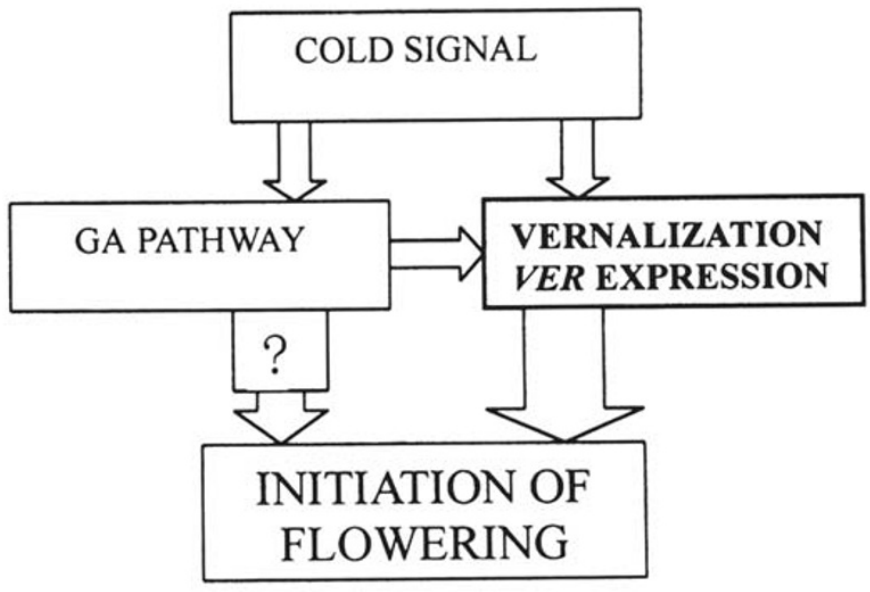

Fig 8. Working model of ver203 gene 
Existence of the ver homologous gene in diverse higher plant species

control flowering in GA action pathway during vernalization.

DNA homologues corresponding to verc203 widely exists in higher plants and they are conserved based on the results of hybridization and PCR (Fig 1 and 2). The ver203 exists extensively in the 16tested representative angiosperms and the tested model plants. The phylogenetic tree of the ver203 gene in tested plants was supported by evolution relationship of species (Fig 3)[16]. Gene corresponding to the ver203 exists with single or low copies in the model plant species tested. The specificity of expression patterns displayed not only in the temporality of development but also in the spatiality of tissues in winter wheat (Fig 5). The sugar of the endosperm is essential for seedling to accept vernalization signal[17]. The ver203 might be one of the most important genes to control the vernalization process of sugar-mediated (Fig 6). As the homological gene corresponding to ver203 expressed at low temperature for 14 days in Arabidopsis thaliana, it may have a similar expression pattern to that in winter wheat that requires vernalization. Arabidopsis, however may provide a possibility to identify biological functions of ver203 gene. The wide existence of the homologous gene corresponding to ver203 suggests that there may be some common pathways in initiating flowering in higher plants. GA could accelerate the expression of gene corresponding to ver203 in Arabidopsis during vernalization, and low temperature was also necessary for the gene expression.

\section{ACKNOWLEDGMENTS}

This work was supported by the National Natural Science Foundation of China (39870060), the state climbing program and the Innovation Project of the Chinese Academy of Sciences (CAS), as well as the Major State Basic Research Program of China (G1999011600). Authors thank Professor Yong Biao XUE of Institute of Developmental Biology, CAS, Professor Shu Nong BAI and Professor Hong Ya GU of Peking University for their comments and help in the isotope experiments. Authors are grateful to Dr Jayakumar Pon (Dow AgroSciences LLC, Indianapolis, USA) for critical reading and linguistic comments to this manuscrept.

\section{REFERENCES}

[1] Law C. In: The Molecular Biology of Flowering, Jordan, B. R.ed, CAB International. 1993; ISBN 0851987230

[2] Chandler J, Wilson A, Dean C. Arabidopsis mutants showing an altered response to vernalization. Plant J. 1996; 10: 637-44.

[3] Chong K, Wang LP, Tan KH, Huang HL, Liang HG. Molecular cloning and characterization of vernalizationrelated (ver) genes in winter wheat. Physiol Plant 1994; 92:511-5.

[4] Chong K, Tan KH, Huang HL, Liang HG. Molecular cloning of a cDNA related to vernalization in winter wheat. Sci China (Ser B) 1995; 38:799-806.

[5] Zhao DZ, Chong K, Wan L, Xu. J, Tan KH. Molecular cloning of a Vernalization-related cDNA clone (vrc) of vrc79 in winter wheat (Triticum aestivum L.). Acta Botanica Sinica 1999; 41:34-9.

[6] Putterill J, Robson F, Lee K, Simon R, Coupland G. The CONSTANS gene of Arabidopsis promotes flowering and encodes a protein showing simlarities to zinc finger transcription factors. Cell 1995; 80:847-57.

[7] Macknight R, Bancroft I, Page I. A gene controlling flowering time in Arabidopsis, encodes a protein containing RNA-binding domains. Cell 1997; 89:737-47.

[8] Michaels SD, Amasino RM. FLOWERING LOCUS C Encodes a novel MADS domain protein that acts as a repressor of flowering. Plant Cell 1999; 11:949-56.

[9] Sheldon CC, Burn JE, Perez PP, Metzger J, Edwards JA, Peacock WJ, Dennis ES. The FLF MADS box gene: A repressor of flowering in Arabidopsis regulated by vernalization and methylation. Plant Cell 1999; 11:445-58.

[10] Johanson U, West J, Lister C, Michaels S, Amasino R, Dean C. Molecaular analysis of FRIGIDA, A major determinant of natural variation in Arabidopsis flowering time. Science 2000; 290:344-7.

[11] Nelson DC, Lasswell J, Rogg LE, Cohen MA, Bartel B. FKF1, a clock-controlled gene that regulates the transition to flowering in Arabidopsis. Cell 2000; 101: 331-340.

[12] Chong K, Bao SL, Xu T, Tan KH, Liang TB, Zeng JZ, Huang $\mathrm{HL}, \mathrm{Xu} \mathrm{J}, \mathrm{Xu} \mathrm{ZH}$. Functional analysis of the ver gene using antisense transgenic wheat. Physiol Plant 1998; 102: 87-92.

[13] Yong WD, Chong K, Liang TB, Xu ZH, Tan KH, Zhu ZQ. Cloning and characterization of vernalization-related gene (ver203F) cDNA 3' end. Chinese Science Bulletin 1999; 44:1289-94.

[14] Dellaporta SL, Wood J, Hicks JB. A plant DNA minipreparation: Version II. Plant Mol Biol Rep 1983; 1: 19-21.

[15] He YK, Xue WX, Sun YD, Yu XH, Liu PL. Leafy head formation of the progenies of transgenic plants of Chinese cabbage with exogenous auxin genes. Cell Research 2000; 10:151-6.

[16] Wang WT. An introduction to four important current systems of classification of the angiosperms (I). Chinese Bulletin of Botany 1990; 7(2):1-7.

[17] Yong WD, Chong K, Xu ZH, Tan KH, Zhu ZQ. Gene control of flowering time in higher plants. Chinene Science Bulletin $2000 ;$ 45:455-66.

[18] Purvis ON. The physiology analysis of vernalization. 
Encyclopedia of Plant Physiology (ed. W. Ruland) 1961; 14:pp. 76-122.

[19] Xu YY, Chong K, Xu ZH, Tan KH. Expression patterns of a vernalization-related genes responding to jasmonate. Acta Botanica Sinica 2001; 43(8):871-3.

[20] Brown JWS, Simpson GG. Splice site selection in plant pre-mRNA splicing. Annu Rev Plant Mol Biol 1998; 49: 77-95.

[21] Patrick DL, William DP. Transcript accumulation and utilzation of alternate and non- consensus splice sites in rice granule-bound starch synthase are temperature- sensitive and controlled by a single-nucleotide polymorphism. Plant Mol Biol 1999; 40:719-27.

[22] Nelson DC, Lasswell J, Rogg LE, Cohen MA, Bartel B. FKF1, a clock-controlled gene that regulates the transition to flowering in Arabidopsis. Cell 2000; 101:331-40.

[23] Burn JE, Babnall DJ, Metzger JD, Dennis ES, Peacock W. J. DNA methylation, vernalization, and the initiation of flowering. PNAS USA 1993; 90:287-91. 